\title{
Retreat but no surrender: Net-spinning caddisfly (Hydropsychidae) silk has enduring effects on stream channel hydraulics
}

\section{Authors: Zachary Maguire, Benjamin B. Tumolo, and Lindsey K. Albertson}

This is a post-peer-review, pre-copyedit version of an article published in 'Hydrobiologia'. The final authenticated version is available online at: https://doi.org/10.1007/s10750-020-04210-4. The following terms of use apply: https://www.springer.com/gp/open-access/publication-policies/aamterms-of-use.

Maguire, Zachary, Benjamin B. Tumolo, and Lindsey K. Albertson. "Retreat but No Surrender: Net-Spinning Caddisfly (Hydropsychidae) Silk Has Enduring Effects on Stream Channel Hydraulics." Hydrobiologia 847, no. 6 (February 28, 2020): 1539-1551. doi:10.1007/ s10750-020-04210-4. 
Retreat but no surrender: Net-spinning caddisfly (Hydropsychidae) silk has enduring effects on stream channel hydraulics

\author{
Zachary Maguire $^{1}$, Benjamin B. Tumolo ${ }^{1}$, and Lindsey K. Albertson ${ }^{1}$
}

Author affiliation: ${ }^{1}$ Department of Ecology, Montana State University, Bozeman, MT, 59717, USA

Corresponding author: Lindsey K. Albertson, PO Box 173460, Montana State University, Bozeman, MT, 59717, USA; Tel: (406) 994-3725; Email: lindsey.albertson@montana.edu

Running title: Aquatic insect silk retreats alter water flow 


\begin{abstract}
Animals and plants engineer their physical environment by building structures that create or modify habitat. Biotic effects on physical habitats can influence community composition, trophic dynamics, and ecosystem processes, however the scales and mechanisms regulating the importance of biotic engineering effects are not well documented. We used a laboratory experiment with common and abundant silk net-spinning caddisflies (Trichoptera:Hydropsychidae) to investigate how biotic structures built in riverbeds influence fluid dynamics at micro spatial scales $(1 \mathrm{~cm})$ over two months. We made velocity measurements with accoustic doppler velocimetery around caddisfly silk structures to test how they influence flow velocity and whether these effects are maintained after the structure is abandoned. We found that caddisfly retreats reduced flow downstream by $85 \%$ and upstream by $17 \%$ compared to gravels without caddisfly retreats. We also found that experimentally abandoned caddisfly retreats could persist for at least 60 days, suggesting legacy effects of the structures. Although aquatic insects are rarely accounted for in hydrological models, our study suggests that small but numerous caddisfly larvae could have substantial hydraulic effects. Future work could address variation in the magnitude and duration of biotic engineering among different silk-producing species, densities through space or time, and hydrologic regimes.
\end{abstract}

Key words: aquatic insect, ecohydrology, ecosystem engineer, habitat modification, legacy effect, velocity 


\section{Introduction}

Organisms that maintain, modify, or create habitat for themselves or other species can have substantial effects on environmental physical processes (Jones et al., 1994; Jones, 2012). These effects derive from activity of animals and plants that range in body size, abundance, and behaviors and can result in a fundamental influence on landscape features (Cuddington et al., 2007). Although a large body of research has focused on the engineering role of vegetation, the potential importance of animals as ecosystem engineers is increasingly recognized (Romero et al., 2015). For example, burrowing of terrestrial invertebrates such as termites can regulate soil moisture and nutrient levels (Elkins et al., 1986) and structures built by marine and freshwater invertebrates such as mussels can intercept flow and provide space for other organisms (Gutiérrez et al., 2003). However, despite progress toward identifying casestudies of ecosystem engineering taxa, the scales and mechanisms regulating ecosystem engineering effects are often not well documented.

In river ecosystems, invertebrates have long been recognized as important drivers of ecosystem function, providing substantial insight into patterns of disturbance (Resh et al., 1988; Lytle \& Poff, 2004; Herbst \& Cooper, 2010), biotic interactions (Hemphill \& Cooper, 1983; Heino et al., 2003; Holomuzki et al., 2010), and processing of material (Vannote et al., 1980; Wallace \& Webster, 1996). A growing body of research also demonstrates how invertebrates drive the processes that shape their physical environments. Variation in physical factors such as flow velocity influences the abundances and distributions of river organisms (Poff et al., 1997), and at the same time, it is increasingly recognized that these animals themselves are major controls of physical dynamics (Rice et al., 2012; Albertson \& Allen, 2015). For example, blackfly larvae produce sticky silk that enhances colonization of biofilm communities (Hammock \& Bogan, 2014). Stonefly larvae modify microhabitat quality as they pursue prey by vigorously moving sediments out of interstitial spaces in gravel beds (Zanetell \& Peckarsky, 1996). Crayfish regulate sediment transport at baseflow by suspending fine sediment (Harvey et al., 2014), with especially pervasive effects on physical processes and native communities in areas where they are invasive (Wilson et al., 2004; Kuhlmann \& Hazelton, 2007). Taken together, the relationships and 
feedbacks between river invertebrates and their physical environments are important to understanding the functionality of freshwater ecosystems.

Reciprocal relationships between organisms and physical flow characteristics of river ecosystems are likely to result in feedbacks that operate over various spatial and temporal scales (Naiman et al., 1999; Fisher et al., 2007; Corenblit et al., 2008). Flow can be described, measured, and modeled at a variety of spatial scales, from local patterns operating over seconds to large trends operating over centuries (Blöschl \& Sivapalan, 1995; Anderson et al., 2006). An important step in refining predictions of the forces that influence hydrodynamics, including local-scale hydraulics, is to include animal-physical interactions (Moore, 2006; Jones, 2012). For example, macrophytes can alter flow conditions and create novel habitats for other organisms who utilize the altered flow regime (Dodds, 1991; Sand-Jensen, 1998; Cornacchia et al., 2019). Identifying legacy effects that occur either over extended time scales or after the engineering organism abandons its structure could help detect the temporal and spatial extent over which ecosystem engineers are most important. For example, fossil records demonstrate that caddisfly nets and retreats altered paleo tufa deposition (Drysdale et al., 2003) and aggregations of case building caddisflies that created carbonate mounds affected sedimentary development of nearshore lake habitats over geologic timescales of $\sim 50$ million years (Leggitt \& Cushman, 2001). Furthermore, net-spinning caddisflies show larger-scale effects on stream ecosystem processes like decadal sediment flux and interstitial velocities that initiate from micro-scale habitat modifications (Juras et al., 2018; Albertson et al., 2019). Despite recognition that ecosystem engineering could have far reaching spatial and temporal influences, measurements of the extent of structures produced or altered by animals in streams are still rare (Hastings et al. 2007; Cuddington, 2011).

To study invertebrate influences on near-bed flow hydraulics over time we studied net-spinning caddisfly insect larvae. Caddisflies in the family Hydropsychidae are aquatic as larvae, spending several months to a year in the water before emerging into nearby terrestrial habitat as adults to mate and lay eggs. As larvae, they require flowing, well-oxygenated water and occupy a variety of habitat types including gravel and cobble beds, travertine step pools, and stationary woody debris (Wiggins, 1977; 
Mackay and Wiggins, 1979; Morse et al. 2019). They produce silk threads that they weave into a mesh catchnet and retreat that they use to filter food particles from the water column. These silk structures can occupy surfaces and pores of substrates and their location is strongly influenced by velocity and food availability (Hildrew \& Edington, 1979; Georgian \& Thorpe, 1992). Detailed work has described how caddisfly silk net retreats influence food delivery (Cardinale et al., 2002; Brown et al., 2005) and geomorphological characteristics such as incipient sediment motion and bedload transport by binding gravels together and increasing critical shear stress required for motion (Statzner et al., 1999; Cardinale et al., 2004; Johnson et al., 2009; Albertson et al., 2014b). Some evidence also suggests that the silk structures influence local hydraulics by slowing down flow and altering turbulence (Cardinale et al., 2002; Juras et al. 2018). These changes to the physical geomorphological and hydrological conditions at the riverbed potentially provide a low flow refuge for other aquatic insects (Nakano et al., 2005; Tumolo et al., 2019). However, we still have limited measurements of caddisfly silk structures on local flow velocity or estimates of how long any potential effects on hydraulics may persist following the loss of the caddisfly. Importantly, these types of micro-scale measurements documenting the effect of caddisfly structures on hydraulics could be useful in better parameterizing broader scale models of near-bed flow velocity, shear stress, and sediment transport (Juras et al., 2018).

To investigate how the silk structure of a common aquatic insect influences micro-scale hydraulics in streams, we used a laboratory experiment to measure how caddisfly silk net retreats alter water velocity. We asked the following questions: Do caddisfly retreats influence local flow? Do they continue to alter velocity over time? And, how long do retreats last once abandoned? This study provides insight into the potential impacts that insects exert on hydrodynamics. Furthermore, this study elucidates the role of animal-influenced local-scale hydraulics that could be important for upscaling to models of benthic community composition, abundance, and processes such as nutrient delivery and sediment erosion. 


\section{Materials and Methods}

\section{Study organism and collection}

Net-spinning caddisflies in the family Hydropsychidae filter-feed by producing silk that they weave into a mesh catchnet attached to a retreat used as refuge when not feeding. We refer to this biogenic structure as the silk structure or silk net retreat. Caddisfly densities within the Rocky Mountain West where our study was performed range from $100 \mathrm{~s}$ to over $7,000 \mathrm{~m}^{-2}$, with individuals building their silk net retreats on the upper or lower surfaces of grains, as well as in pore spaces (Oswood, 1979; Hauer \& Stanford, 1982; Valett \& Stanford, 1987). For the experiment, caddisfly retreats were collected by hand in Bozeman Creek $\left(45^{\circ} 40^{\prime} 33^{\prime \prime} \mathrm{N}, 111^{\circ} 01^{\prime} 55^{\prime \prime} \mathrm{W}\right)$ by carefully selecting gravels of approximately $60 \mathrm{~mm}$ $b$-axis (or intermediate) diameter. Each gravel selected had a single retreat positioned approximately in the rock's center and on the top surface. We targeted this precise arrangement of the retreat (on the rock surface) and a consistent rock size as the primary goal of the sampling scheme instead of targeting any particular species of hydropsychid, and as a result, our inferences about the effects of silk net retreats on hydraulics can only be drawn to the family level. This sampling technique resulted in a total of 29 caddisflies of the family Hydropsychidae. Caddisflies and their corresponding retreats attached to rocks were collected on the $29^{\text {th }}$ of November, 2017 and moved to the laboratory for the experiment by carefully securing the rocks in a cooler of stream water within 60 minutes so that the silk structures were not disturbed or dried out during the moving process. Rocks of the same size (60 mm diameter $b$-axis) without caddisfly structures were used as controls (hereafter 'control') to measure and characterize flow over smooth gravel surfaces without the influence of caddisfly silk net retreats. These control rocks were selected from the stream at the same time as caddisfly retreat rocks. To test legacy effects on flow and persistence of the retreat structures in a laboratory stream, the retreats were experimentally abandoned. Caddisflies were encouraged to abandon their retreat by gently poking each retreat with blunt forceps, an activity that easily encourages caddisflies to move out of the front end of their retreat. Retreats were not used for the experiment if no caddisfly was initially present. We measured the size of the caddisfly individuals that were removed from the retreats used in the experiment and they averaged $18.24 \pm \mathrm{SE}$ 
$0.66 \mathrm{~mm}$ in length, indicating that all individuals were fourth instar developmental stage and similar in body size, indicated by the small variation about the mean.

\section{Experimental design}

We conducted this experiment in laboratory flumes (Fig. 1a,b) housed at Montana State University, Bozeman Montana, USA. The flumes (1.2-m long '0.15-m wide ' 0.20-m deep) have a motor attached to a shaft and propeller that recirculates water through the flume and over the observational sediment units using an electrical speed control box (Albertson et al., 2014a). Caddisfly silk net retreats were housed in three holding flumes where velocity was held constant at $0.15 \mathrm{~m} \mathrm{~s}^{-1}$ (Fig. 1a). Each silk net retreat on a rock was paired with a control rock of similar size and weight but with no retreat present on its surface. The control rocks were also housed in the holding flumes. To investigate whether the caddisfly retreats influenced local flow, we measured velocity on day $1,3,5,10,15,30,45$, and 60 of the experiment. Day 1 occurred on the $1^{\text {st }}$ of December, 2017. During measurement days, silk net retreat rocks or control rocks were individually placed in a fourth experimental flume (Fig. 1b) where velocity in the water column was measured for control rocks at one location in the center and $5 \mathrm{~mm}$ above the rock surface and for retreat rocks at two locations $5 \mathrm{~mm}$ above the rock surface at (i) $5.0 \mathrm{~mm}$ in front of and (ii) $5.0 \mathrm{~mm}$ behind each retreat (Fig. 1c,d). This sampling scheme resulted in three treatments: upstream of a caddisfly structure, downstream of a caddisfly structure, and smooth-surface control. We measured velocity in two locations around the silk net retreat structure but just a single location for the smoothsurface control because we expected that the structure itself might influence flow velocity in multiple directions if it created an upstream eddy or downstream current shadow. We made substantial efforts to take spatially consistent measurements throughout the duration of the experiment by placing rocks at the same depth, orientation, and location during each measurement day. Retreats were used as a landmark so that the rock was placed into the experimental flume with the retreat at the flume's longitudinal centerline and the retreat opening oriented perpendicular to the flow. When individual silk 
net retreat rocks were moved to the experimental flume, velocity was initially $0 \mathrm{~ms}^{-1}$ and then slowly raised with the speed control box to $0.3 \mathrm{~ms}^{-1}$ to avoid loss of material due to flow shock. Levels of nearbed flow used in this experiment $\left(0.15-0.3 \mathrm{~ms}^{-1}\right)$ are representative of nature and typical of those used to study net-spinning caddisflies (Carling et al., 1992; Albertson et al., 2014a). To quantify degradation of the silk over time, each silk net retreat was photographed immediately before velocity measurements were taken on each measurement day from the same angle and distance using a custom landmarked grid and digital camera (Fig. S1). When measurements were complete, the retreat and control rocks were returned to their holding flume.

\section{Characterizing flow and the caddisfly retreats}

All flow velocity measurements were taken using a Vectrino micro acoustic doppler velocimeter (ADV) at a measurement rate of $25 \mathrm{~Hz}$ (Nortek, Norway). This velocity meter was chosen for its ability to offer high spatial accuracy velocity measurements in small sampling volumes (Nortek 2005) close to the streambed (Brand et al. 2016). Velocity was measured at $5 \mathrm{~mm}$ above the rock surface at the location 5 $\mathrm{mm}$ upstream and $5 \mathrm{~mm}$ downstream of each silk net retreat. In control rocks, velocity was measured in the rock center and $5 \mathrm{~mm}$ above the rock surface. The experiment was designed in this way because measurements were taken over two months for each retreat, so that the retreat itself could not be removed to make a smooth-surface comparison on the same exact rock. Instead, we used a paired, control rock as a smooth-surface comparison by necessity. For the measurements taken upstream and downstream of the retreat structure, the sample area volume of the ADV (called the sampling cell) was $4 \mathrm{~mm}$ tall by $1 \mathrm{~mm}$ wide and was placed in the horizontal center of the retreat structure (Nortek 2005). For the silk net retreat rocks, we estimated the reduction in flow caused by the retreat, calculated as the downstream flow minus the upstream flow. We expected some measurement variation across all rocks, including those in control treatments, across measurement days because the advanced-technology ADV takes high resolution velocity measurements that are sensitive to small differences in probe or rock placement. The potential sources of measurement error associated with this variation do not, however, override our ability to detect 
how the caddisfly retreats alter water velocity or compare velocity measurements across our experimental treatments (Fig. S3). Retreat height was measured as a possible covariate to explain variation in the any hydrologic response. Height was measured from silk net retreat photographs using ImageJ software as the vertical distance in $\mathrm{mm}$ from the upper most surface of retreat perpendicular to the retreat's attachment site at the rock's surface.

\section{Data analysis}

Flow velocities and retreat height were compared across treatments over the duration of the experiment using linear mixed effects models. A linear mixed effect model comparing flow velocities among treatment locations over the duration of the experiment included the fixed effects of treatment and day and the random effects of individual retreat and individual retreat nested within sampling date. In addition to comparing velocity among treatments we analyzed changes in retreat height throughout the experiment using a separate linear mixed effects model. Differences in retreat height were compared across three levels of persistence (low $=31$ days, medium $=45$, and high $=61$ ), and persistence was defined as the presence of the silk net retreat on the rock surface during the particular measurement period. Retreat height was compared across persistence level using a linear mixed effect model with persistence and day as fixed effects and the random effects of individual retreat and individual retreat nested within day. Both of these linear mixed effect models used day as a categorical variable and accounted for the non-independence of samples taken on the same study retreat over multiple sampling events by using a standard mixed model repeated measures design where individual retreat was nested within sampling day (Bolker, 2008; Zuur et al., 2009). All mixed effects models were fit with the lme4 package (Bates et al., 2015) and significance was tested using a Kenward-Roger denominator degrees of freedom approximation (Kenward \& Roger, 1997; Bolker et al., 2009). Post-hoc comparisons of least squares means and confidence intervals for response variables between treatments were calculated using the lsmeans function (Lenth, 2016). Linear regression was used to test for a relationship between retreat 
height and flow reduction. All linear mixed effects model, and linear regression analyses were conducted using R version 3.3.1 (R Development Core Team, 2016).

\section{Results}

Caddisfly silk retreat structures influenced local flow velocity and persisted for much longer than expected. We detected a significant negative effect of retreat presence on local flow velocity $\left(\mathrm{F}_{2,384}=424.81, \mathrm{P}=0.001\right.$; Fig. 2 , Tables 1,2$)$. Velocity was $81 \%$ lower downstream of abandoned retreats compared to upstream of retreats $\left(0.035 \pm 0.008\right.$ vs. $\left.0.192 \pm 0.008 \mathrm{~m} \mathrm{~s}^{-1} \mathrm{~T}_{385}=-24.863, \mathrm{P}=0.001\right)$. Additionally, flow velocity was $84 \%$ lower downstream of retreats compared to the surface of control rocks $\left(0.035 \pm 0.008\right.$ vs. $\left.0.229 \pm 0.008 \mathrm{~m} \mathrm{~s}^{-1}, \mathrm{~T}_{384}=28.659, \mathrm{P}=0.001\right)$, and $17 \%$ lower upstream of retreats compared to control rocks $\left(0.192 \pm 0.008\right.$ vs. $\left.0.229 \pm 0.008 \mathrm{~m} \mathrm{~s}^{-1}, \mathrm{~T}_{385}=3.877, \mathrm{P}=0.001\right)$. Although retreats consistently reduced down- and upstream-flow compared to control rock surfaces for the duration of the 61-day experiment (Table 2; Figs. 2, 3), velocity did vary across all three treatments over the eight measurement days (Table 1; Fig. 3), with the most pronounced variation on days 1, 5 and 15 (Fig. S3). The range of retreat sizes used in this experiment reduced near-bed flow velocities at comparable magnitudes, and we detected no correlation between retreat height and a reduction in flow $\left(\mathrm{R}^{2}=0.043, \mathrm{P}=\right.$ 0.282; Fig. S2). We observed that all 29 abandoned caddisfly retreats (100\%) persisted for at least 15 days, with 97\% (28 retreats) lasting 31 days, 79\% (23 retreats) for 45 days, and 59\% (17 retreats) for 60 days (Fig. 3).

Given the differences in persistence that we observed, we categorized the duration that retreats lasted as persistence levels of 31,45 , or 60 days. We detected a significant interactive effect of persistence level and day on retreat height $\left(\mathrm{F}_{11,165}=1.88, \mathrm{P}=0.046\right.$; Table 3$)$, suggesting that changes to retreat height over time varied differently for the different persistence levels (Fig. 4). Overall retreat height declined throughout the experiment when pooled across all persistence levels by $2.1 \mathrm{~mm}$. Retreats that persisted for shorter amounts of time appeared to change height the most while retreats that persisted for the entire duration of the experiment maintained their height (Fig. 4). 


\section{Discussion}

Animals and plants can influence physical ecosystem processes, but the magnitudes, scales, and mechanisms controlling these biotic forces are not well documented. Here, we show that a silk net retreat built by a common aquatic insect, the hydropsychid caddisfly, can reduce flow velocity by up to $85 \%$. Additionally, the persistence of silk net retreats recorded in this study exceeds that of any previous reports of which we are aware by $4 \times$ (Albertson $\&$ Daniels, 2016). The findings from this experiment support those from fluid dynamics modelling showing that simulated, aggregated hydropsychid silk structures in the pore spaces of a gravel bed $\left(0.2 \mathrm{~m}^{2}\right)$ can reduce velocity at larger spatial scales by up to $70 \%$ when measuring the influence of multiple silk structures (Juras et al., 2018). Previous work shows that caddisfly silk structures of populations of this filter-feeding insect are arranged to maximize interception of flow, suggesting that changes to near-bed hydraulics induced by these insects may influence not only the physical process itself, but also ecological processes such as food delivery rates (Georgian \& Wallace, 1981; Cardinale et al., 2002). Our findings also provide evidence that a reduction in flow velocity may extend both upstream and downstream of the structure, highlighting the need for a more detailed, mechanistic understanding of the spatial extent to which biology influences physical processes.

Although most work investigating biotic influence on flow has focused on larger species such as fish or crustaceans, our experiment reveals that small but numerous aquatic insects could also have a strong biotic influence (Albertson \& Allen, 2015; Romero et al., 2015). Conspicious vegetation, woody debris jams, and beaver dams are widely recognized to impact channel flow, groundwater exchange, water storage, and timing of discharge (Naiman et al., 1988; Edwards et al., 1999; Herberholz et al., 2007; Kramer \& Wohl, 2015). In other stystems, large structures such as corals influence wave action (Quataert et al., 2015) and mussel beds modulate water currents (Walker \& Grant, 2009). Probably because of their small size, aquatic macroinvertebrates as engineers have largely been ignored despite mounting evidence suggesting they could play a large role in creating or modifying natural environments (Romero et al., 2015). For example, midge (Chironomidae: Diperta) larvae stabilize sediments in ways that influence 
crustacean cladoceran communities (Webert et al., 2017). Mussels and crayfish alter sediment stability and sorting dynamics (Creed \& Reed, 2004; Allen \& Vaughn, 2011). Hydropsychid caddisflies increase calcium carbonate precipitation in travertine streams, potentially by reducing flow velocity (Drysdale,

1999). Hydraulic models show that simulated aggregations of hydropsychid caddisfly nets at a density of $735 \mathrm{~m}^{-2}$ reduce near-bed velocity and shear stress by decreasing interstitial flow (Juras et al. 2018). Thus, micro-scale impacts of individual net-spinning caddisflies like those observed in our study likely propagate to broader spatial scale effects on stream hydraulics and shear stress when multiple caddisflies are present in a stream. If these small but often abundant animals influence physical processes and habitat formation in natural streams, the consequences could be wide reaching for biological communities and ecosystem functions. For example, the silk structures can provide a low flow refuge to mayflies (Nakano et al., 2005) and influence colonization patterns of other benthic invertebrates (Tumolo et al., 2019). The physical response of stream fluid dynamics to insect structures is understudied but could play a key role in identifying the feedbacks that exist between aquatic insects and hydrological and geomorphological processes (Albertson \& Allen, 2015). Extensive research has identified the micro-scale habitat features, including water velocity, that regulate caddisfly colonization and habitat selection (Osborne \& Herricks, 1987; Georgian \& Thorpe, 1992; Harding, 1997). At the same time, our analysis echos a growing body of literature showing that these organisms themselves may be influencing local water flow dynamics. If insects are building structures that influence flow patterns at river bed surfaces, this effect may alter flow patterns in several ways, including velocity, velocity profiles, and drag on substrate (Wilcock, 1996; Church, 2006; Juras et al., 2018). Most of the work to date investigating caddisfly engineering has focused on the geomorphological consquence of silk for sediment movement (Statzner et al., 1999; Cardinale et al., 2004; Johnson et al., 2009). If caddisflies are altering flow patterns within the bed when they build silk structures in pores or the bottom surfaces of gravels, then caddisflies may also alter the connection between the river channel and groundwater by influencing hyporheic exchange and vertical hydraulic gradient. Previous work in streams has shown that other 
macroinvertebrate behavior below the riverbed surface can increase streambed hydraulic conductivity and enhance hyporheic exchange through bioturbation (Song et al., 2010). In other ecosystems, biological activity of biofilms, insects, or vegetation can markedly influence infiltration rates and hydraulic conductivity that ultimately has a large influence on soil crusts and macropores (Elkins et al., 1986; Tongway et al., 1989; Anderson, 2000). Our results show a large reduction in flow velocity $5 \mathrm{~mm}$ downstream of structures built at the rock surface, potentially occuring because of increases in drag and current blocking. We also show considerable flow reduction imediately upstream $(5 \mathrm{~mm})$ of retreats, possibly due to eddy formation or current blocking. Because we made point measurements of velocity at 5 $\mathrm{mm}$ above the rock surface and all of the retreats in our study were $5 \mathrm{~mm}$ or larger in height, it is not surprising that we did not detect a relationship between retreat height and flow reduction. However, natural silk net retreats of variable size could still differentially influence flow by altering near bed roughness and turbulence throughout the water column and in pore spaces. Future hydraulic modelling efforts might consider how important ecological complexities such as microdistributions of the engineer (i.e. caddisflies occupying tops, bottoms, or sides of grains; subsurface grains) and size of the biotic structure influences patterns of flow.

Some of the retreats in our study lasted longer than others, suggesting variation in caddisfly engineering that may result from several non-mutually exclusive factors. Hydropsychid caddisflies have alternative forms of silk structures depending on several environmental factors, including pollutants, flow velocity, and species (Petersen \& Petersen, 1983; Loudon \& Alstad, 1992; Balch et al., 2000; Wiggins, 2007; Albertson et al., 2014b). A growing body of literature highlights the importance of both inter- and intraspecific trait variation in modulating animal-environment realtionships (Bolnick et al., 2011; Balik et al., 2018). In our study system, this variation in form and durability of the caddisfly retreat structures could mediate how much a particular retreat influences local flow conditions since evidence does suggest that net-building design is plastic and not under strict genetic control (Plague \& McArthur, 2003). Variation could result from how individuals create the architecture and geometry of their silk net retreat, composition of the retreat material including small pebbles and twigs, tensile strength and durability of 
the silk, building position and thus exposure to flow, proximity to neighboring retreats and velocity shadows, life history instar stage and size, and previous amount of time in the river before being harvested for this experiment. The importance of considering this variation is highlighted by our observations that smaller silk net retreats appeared to persist for the longest amount of time, perhaps because they were in lower chronic velocities than relatively tall retreats protruding into the near-bed flow. Future work might specifically consider genus and species identity since other caddisfly genera, such as Macronema, have fundamentally different tube nets that could intercept flow differently from hydropsychid nets (Mackay \& Wiggins, 1979). In this experiment, we can only draw conclusions about the effects of Hydropsychidae on micro-scale flow dynamics, but it will be important to investigate differences in flow-reducing ability across different genera or species.

Although caddisflies tend their nets to repair damage and maintain the most efficient structure (Runde \& Hellenthal, 2000), events happen in natural streams that may cause a caddisfly to leave or abandon its structure. We hypothesized that unattended silk retreat structure could have legacy effects. Although we have not tested which of these mechanisms are operating the most frequently, a structure may be unattended if the caddisfly drifts downstream during a flood, gets eaten by a predator, or finds a more suitable net-building location. Other caddisflies may then colonize the abandoned structure, or the structure may be left to degrade (Englund \& Olsson, 1990). In our study, we demonstrate for the first time that these structures may last up to two months, albiet in a simulated stream. However, next steps will be to document caddisfly retreat effects on hydraulics over time under natural stream conditions. Other ecosytem engineers are also likely influenced by events that may disrupt or reset the engineering structure or activity through space or time, resulting in feedbacks (Reinhardt et al., 2010; Atkinson et al. 2018). Future work could document how long these structures last in a natural stream that has variation in flow conditions, water temperatures, and potential for recolonization by new engineers, which are all important features that may increase or decrease decay rates.

The scale of our experiment highlights the importance of time and space in regulating biotic effects on physical conditions. Temporal legacies of larger biogenic structures create macro-habitats and 
ecotones that act as important ecological refugia. For example, coral reefs or beaver dams continue to provide nursery grounds for fish long after the death of the engineer (Burchsted et al., 2010). Legacies of ecogeomorphic processes such as ecosytem engineering can be important for understanding current processes and predicting future trajectories (Harding et al., 1998). Understanding the scale of influence of ecosystem engineers has been called for, yet we still lack information defining precise physical effects of structures. Furthermore, we have yet to then use this information to effectively predict the spatio-temporal extent of engineering impacts (Wright \& Jones, 2006; Hastings et al., 2007). Recent research highlights how ecosystem engineering and modification of burrowing structures in soil regulates precipitation legacies and thus vegetation communities over long time scales (Grinath et al., 2018). In our study system, temporal fluctuations in the number of silk net retreats present in the streambed as caddisflies move through their natural life cycle and build pupal cases to merge as adults could ultimately add complexity to their effects on physical processes and dictate when and where these effects on flow are most important (Benke \& Wallace, 1980; Benke \& Huryn, 2010). The measurements in this study are admittedly on spatial scales immediately relevant to a single caddisfly silk structure. However, alteration to near bed flow at these relatively small spatial scales is pertinent for habitat selection by diatoms and macroinvertebrates (Pringle, 1985; Davis \& Barmuta, 1989). Futhermore, caddisflies can reach densities of over $10,000 \mathrm{~m}^{-2}$, resulting in a matrix of thousands of silk net retreats arranged on the streambed and within gravels (Cardinale et al., 2002; Albertson et al., 2019). An exciting area for future research is to address how spatial variation in biotic structure density, size, and arrangement influences fluid dynamics. Understanding how biology controls physical proceesses is becoming increasingly relevant in light of altered hydrological and geomorpholocial regimes. Ecosystem engineering and the mechanisms regulating biotic effects are understudied but could play a fundamental role in shaping natural ecosystems (Gribben et al., 2009). Further understanding of the mechanisms and scales involved in biogenic effects on flow could help determine how to better incorporate biotic structures into physical process models (Reinhardt et al., 2010; Atkinson et al., 2018). 


\section{Acknowledgements}

We thank M. J. MacDonald and M. A. Horvath for field and laboratory assistance, and K. Plymesser and L. S. Sklar for advice on previous versions of this manuscript. Three anonymous reviewers provided excellent comments.

\section{Contribution of Authors}

All authors designed the study and wrote the paper. ZM and BBT conducted the experiment and analyzed the data.

Funding: Funding for this project was provided by the National Science Foundation (DEB 1556684). ZM was also supported by an Undergraduate Scholars Program grant from Montana State University.

Conflict of Interest: The authors declare that they have no conflicts of interest. 


\section{References}

Albertson, L. K., \& D. C. Allen, 2015. Meta-analysis: Abundance, behavior, and hydraulic energy shape biotic effects on sediment transport in streams. Ecology 96: 1329-1339.

Albertson, L. K., B. J. Cardinale, \& L. S. Sklar, 2014a. Non-additive increases in sediment stability are generated by macroinvertebrate species interactions in laboratory streams. PLOS ONE 9: e103417.

Albertson, L. K., \& M. D. Daniels. 2016. Resilience of aquatic net-spinning caddisfly silk structures to common global stressors. Freshwater Biology 61: 670-679.

Albertson, L. K., L. S. Sklar, S. D. Cooper, \& B. J. Cardinale, 2019. Aquatic macroinvertebrates stabilize gravel bed sediment: A test using silk net-spinning caddisflies in semi-natural river channels. PLoS ONE 14: e0209087.

Albertson, L. K., L. S. Sklar, P. Pontau, M. Dow, \& B. J. Cardinale, 2014b. A mechanistic model linking insect (Hydropsychidae) silk nets to incipient sediment motion in gravel-bedded streams. Journal of Geophysical Research-Earth Surface 119: 1833-1852.

Allen, D. C., \& C. C. Vaughn. 2011. Density-dependent biodiversity effects on physical habitat modification by freshwater bivalves. Ecology 92: 1013-1019.

Anderson, J. M., 2000. Food web functioning and ecosystem processes: Problems and perceptions of scaling In Coleman, D. C., \& P. F. Hendrix (eds), Invertebrates as Webmasters in Ecosystems. CABI Publishing, New York, NY: 3-24.

Anderson, K. E., A. J. Paul, E. McCauley, L. J. Jackson, J. R. Post, \& R. M. Nisbet, 2006. Instream flow needs in streams and rivers: the importance of understanding ecological dynamics. Frontiers in Ecology and the Environment 4: 309-318.

Atkinson, C. L., D. C. Allen, L. Davis, \& Z. L. Nickerson, 2018. Incorporating ecogeomorphic feedbacks to better understand resiliency in streams: A review and directions forward. Geomorphology 305: 123140.

Balch, G. C., R. D. Evans, P. Welbourn, \& R. Prairie, 2000. Weight loss and net abnormalities of 
Hydropsyche betteni (caddisfly) larvae exposed to aqueous zinc. Environmental Toxicology and Chemistry 19: 3036-3043.

Balik, J. A., B. W. Taylor, S. E. Washko, \& S. A. Wissinger, 2018. High interspecific variation in nutrient excretion within a guild of closely related caddisfly species. Ecosphere Wiley-Blackwell 9: e02205.

Bates, D., M. Maechler, B. Bolker, \& S. Walker, 2015. Fitting linear mixed-effects models using lme4. Journal of Statistical Software 67: 1-48.

Benke, A. C., \& A. D. Huryn, 2010. Benthic invertebrate production-facilitating answers to ecological riddles in freshwater ecosystems. Journal of the North American Benthological Society 29: 264-285.

Benke, A. C., \& J. B. Wallace, 1980. Trophic basis of production among net-spinning caddisflies in a southern Appalachian stream. Ecology 61: 108-118.

Blöschl, G., \& M. Sivapalan, 1995. Scale issues in hydrological modelling: A review. Hydrological Processes 9: 251-290.

Bolker, B., 2008. Ecological Models and Data in R. Princeton University Press.

Bolker, B. M., M. E. Brooks, C. J. Clark, S. W. Geange, J. R. Poulsen, M. H. H. Stevens, \& J.-S. S.

White, 2009. Generalized linear mixed models: a practical guide for ecology and evolution. Trends in Ecology \& Evolution 24: 127-135.

Bolnick, D. I., P. Amarasekare, M. S. Araújo, R. Bürger, J. M. Levine, M. Novak, V. H. W. Rudolf, S. J. Schreiber, M. C. Urban, \& D. A. Vasseur, 2011. Why intraspecific trait variation matters in community ecology. Trends in Ecology \& Evolution Howard Hughes Medical Institute 26: 183-192. Brown, S. A., G. D. Ruxton, R. W. Pickup, \& S. Humphries, 2005. Seston capture by Hydropsyche siltalai and the accuracy of capture efficiency estimates. Freshwater Biology 50: 113-126.

Burchsted, D., M. Daniels, R. Thorson, \& J. Vokoun, 2010. The river discontinuum: Applying beaver modifications to baseline conditions for restoration of forested headwaters. BioScience Oxford University Press 60: 908-922.

Cardinale, B. J., E. R. Gelmann, \& M. A. Palmer, 2004. Net spinning caddisflies as stream ecosystem engineers: The influence of Hydropsyche on benthic substrate stability. Functional Ecology 18: 381-387. 
Cardinale, B. J., M. A. Palmer, \& S. L. Collins, 2002. Species diversity enhances ecosystem functioning through interspecific facilitation. Nature 415: 426-429.

Carling, P., A. Kelsey, \& M. Glaister, 1992. Effect of bed roughness, particle shape and orientation on initial motion criteria In Billi, P., R. Hey, C. Thorne, \& P. Tacconi (eds), Dynamics of Gravel-bed Rivers. John Wiley \& Sons Ltd, Chichester, UK: 23-29.

Church, M., 2006. Bed material transport and the morphology of alluvial river channels. Annual Review of Earth and Planetary Sciences 34: 325-354.

Corenblit, D., A. M. Gurnell, J. Steiger, \& E. Tabacchi, 2008. Reciprocal adjustments between landforms and living organisms: Extended geomorphic evolutionary insights. Catena 73: 261-273.

Cornacchia, L., S. Licci, H. Nepf, A. Folkard, D. van der Wal, J. van de Koppel, S. Puijalon \&

T. J. Bouma. 2019. Turbulence-mediated facilitation of resource uptake in patchy stream

macrophytes. Limnology and Oceanography 64: 714-727.

Creed, R. P., \& J. M. Reed. 2004. Ecosystem engineering by crayfish in a headwater stream community. Journal of the North American Benthological Society 23: 224-236.

Cuddington, K., 2011. Legacy Effects: The Persistent Impact of Ecological Interactions. Biological Theory Springer Netherlands 6: 203-210.

Cuddington, K., J. Byers, W. Wilson, \& A. Hastings, 2007. Ecosystem Engineers: Plants to Protists. Academic Press, Burlington, MA.

Davis, J. A., \& L. A. Barmuta. 1989. An ecologically useful classification of mean and near-bed flows in streams and rivers. Freshwater Biology 21: 271-282.

Dodds, W. K., 1991. Community interactions between the filamentous alga Cladophora glomerata, its epiphytes, and epiphyte grazers. Oecologia 85: 572-580.

Drysdale, R. N., 1999. The sedimentological significance of hydropsychid caddisfly larvae (order; Trichoptera) in a travertine-depositing stream; Louie Creek, Northwest Queensland, Australia. Journal of Sedimentary Research 69: 145-150. 
Drysdale, R. N., K. D. Carthew, \& M. P. Taylor, 2003. Larval caddis-fly nets and retreats: a unique biosedimentary paleocurrent indicator for fossil tufa deposits. Sedimentary Geology 161: 207-215. Edwards, P. J., J. Kollmann, A. M. Gurnell, G. E. Petts, K. Tockner, \& J. V. Ward, 1999. A conceptual model of vegetation dynamics on gravel bars of a large Alpine river. Wetlands Ecology and Management Kluwer Academic Publishers 7: 141-153.

Elkins, N. Z., G. V. Sabol, T. J. Ward, \& W. G. Whitford, 1986. The influence of subterranean termites on the hydrological characteristics of a Chihuahuan desert ecosystem. Oecologia 68: 521-528. Englund, G., \& T. Olsson, 1990. Fighting and assessment in the net-spinning caddis larvae Arctopsyche ladogensis: a test of the sequential assessment game. Animal Behaviour 39: 55-62.

Fisher, S. G., J. B. Heffernan, R. A. Sponseller, \& J. R. Welter, 2007. Functional ecomorphology: Feedbacks between form and function in fluvial landscape ecosystems. Geomorphology 89: 84-96. Georgian, T., \& J. E. Thorpe, 1992. Effects of microhabitat selection on feeding rates of net-spinning caddisfly larvae. Ecology 73: 229-240.

Georgian, T., \& J. Wallace, 1981. A model of seston capture by net-spinning caddisflies. Oikos 36: 147157.

Gribben, P., J. Byers, M. Clements, L. McKenzie, P. Steinberg, \& J. Wright, 2009. Behavioural interactions between ecosystem engineers control community species richness. Ecology Letters 12: 11271136.

Grinath, J. B., N. Deguines, J. W. Chesnut, L. R. Prugh, J. S. Brashares, \& K. N. Suding, 2018. Animals alter precipitation legacies: Trophic and ecosystem engineering effects on plant community temporal dynamics. Journal of Ecology 106: 1454-1469.

Gutiérrez, J. L., C. G. Jones, D. L. Strayer, \& O. O. Iribarne, 2003. Mollusks as Ecosystem Engineers: The Role of Shell Production in Aquatic Habitats. Oikos. 101: 79-90.

Hammock, B. G., \& M. T. Bogan, 2014. Black fly larvae facilitate community recovery in a mountain stream. Freshwater Biology 59: 2162-2171.

Harding, J. S., 1997. Strategies for coexistence in two species of New Zealand Hydropsychidae 
(Trichoptera). Hydrobiologia 350: 25-33.

Harding, J. S., E. F. Benfield, P. V. Bolstad, G. S. Helfman, \& E. B. D. Jones, 1998. Stream biodiversity: The ghost of land use past. Proceedings of the National Academy of Sciences 95: 14843-14847. Harvey, G. L., A. J. Henshaw, T. P. Moorhouse, N. J. Clifford, H. Holah, J. Grey, \& D. W. Macdonald, 2014. Invasive crayfish as drivers of fine sediment dynamics in rivers: field and laboratory evidence. Earth Surface Processes and Landforms 39: 259-271.

Hastings, A., J. E. Byers, J. A. Crooks, K. Cuddington, C. G. Jones, J. G. Lambrinos, T. S. Talley, \& W. G. Wilson, 2007. Ecosystem engineering in space and time. Ecology Letters 10: 153-164. Hauer, F. R., \& J. A. Stanford, 1982. Ecological responses of hydropsychid caddisflies to stream regulation. Canadian Journal of Fisheries and Aquatic Sciences 39: 1235-1242.

Heino, J., T. Muotka, \& R. Paavola, 2003. Determinants of macroinvertebrate diversity in headwater streams: regional and local influences. Journal of Animal Ecology 72: 425-434.

Hemphill, N., \& S. D. Cooper, 1983. The effect of physical disturbance on the relative abundances of two filter-feeding insects in a small stream. Oecologia 58: 378-382.

Herberholz, J., C. McCurdy, \& D. H. Edwards, 2007. Direct benefits of social dominance in juvenile crayfish. Biological Bulletin 213: 21-27.

Herbst, D. B., \& S. D. Cooper, 2010. Before and after the deluge: rain-on-snow flooding effects on aquatic invertebrate communities of small streams in the Sierra Nevada, California. Journal of the North American Benthological Society 29: 1354-1366.

Hildrew, A. G., \& J. M. Edington, 1979. Factors facilitating the coexistence of hydropsychid caddis larvae (Trichoptera) in the same river system. Journal of Animal Ecology 48: 557-576.

Holomuzki, J. R., J. W. Feminella, \& M. E. Power, 2010. Biotic interactions in freshwater benthic habitats. Journal of the North American Benthological Society 29: 220-244.

Johnson, M. F., I. Reid, S. P. Rice, \& P. J. Wood, 2009. Stabilization of fine gravels by net-spinning caddisfly larvae. Earth Surface Processes and Landforms 34: 413-423. 
Jones, C. G., 2012. Ecosystem engineers and geomorphological signatures in landscapes. Geomorphology 157: 75-87.

Jones, C. G., J. H. Lawton, \& M. Shachak, 1994. Organisms as ecosystem engineers. Oikos 69: 373-386.

Juras, M., L. K. Albertson, J. Cahoon, \& E. L. Johnson, 2018. Incorporating macroinvertebrate biological structures into gravel-bedded stream fluid dynamics using 3D CFD modelling. Ecological Engineering 119: 19-28.

Kenward, M., \& J. Roger, 1997. Small sample inference for fixed effects from restricted maximum likelihood. Biometrics 53: 983-997.

Kramer, N., \& E. Wohl, 2015. Driftcretions: The legacy impacts of driftwood on shoreline morphology. Geophysical Research Letters 42: 5855-5864.

Kuhlmann, M., \& P. Hazelton, 2007. Invasion of the Upper Susquehanna River watershed by Rusty crayfish (Orconectes rusticus). Northeastern Naturalist 14: 507-518.

Leggitt, V. L., \& R. A. Cushman Jr, 2001. Complex caddisfly-dominated bioherms from the Eocene Green River Formation. Sedimentary Geology 145: 377-396.

Lenth, R. V., 2016. Least-Squares Means: The R Package 1smeans. Journal of Statistical Software 69: 133.

Loudon, C., \& D. N. Alstad, 1992. Architectural plasticity in net construction by individual caddisfly larvae (Trichoptera: Hydropsychidae). Canadian Journal of Zoology 70: 1166-1172.

Lytle, D. A., \& N. L. Poff, 2004. Adaptation to natural flow regimes. Trends in Ecology and Evolution 19: 94-100.

Mackay, R. J., \& G. B. Wiggins, 1979. Ecological diversity in Trichoptera. Annual Review of Entomology 24: 185-208.

Moore, J. W., 2006. Animal ecosystem engineers in streams. Bioscience 56: 237-246.

Naiman, R. J., S. R. Elliott, J. M. Helfield, \& T. C. O’Keefe, 1999. Biophysical interactions and the structure and dynamics of riverine ecosystems: the importance of biotic feedbacks. Hydrobiologia 410: 79-86. 
Naiman, R., C. Johnston, \& J. Kelley, 1988. Alteration of North American streams by beaver. BioScience 38: $753-762$.

Nakano, D., M. Yamamoto, \& T. Okino, 2005. Ecosystem engineering by larvae of net-spinning stream caddisflies creates a habitat on the upper surface of stones for mayfly nymphs with a low resistance to flows. Freshwater Biology 50: 1492-1498.

Nortek. 2005. Vectrino current meter, User Manual, Nortek AS, Norway.

Osborne, L. L., \& E. E. Herricks, 1987. Microhabitat characteristics of Hydropsyche

(Trichoptera:Hydropsychidae) and the importance of body size. Journal of the North American Benthological Society 6: 115-124.

Oswood, M. W., 1979. Abundance patterns of filter-feeding Caddisflies (Trichoptera: Hydropsychidae) and seston in a Montana (U.S.A.) lake outlet. Hydrobiologia 63: 177-183.

Petersen, L. B. M., \& R. C. Petersen, 1983. Anomalies in Hydropsychid capture nets from polluted streams. Freshwater Biology 13: 185-191.

Plague, G. R., \& J. V. McArthur, 2003. Phenotypic plasticity of larval retreat design in a net-spinning caddisfly. Behavioral Ecology 14: 221-226.

Poff, N., D. Allan, M. B. Bain, J. R. Karr, K. L. Prestegaard, B. D. Richter, R. E. Sparks, \& J. C. Stromberg, 1997. The Natural Flow Regime: A paradigm for river conservation and restoration. BioScience 47: 769-784.

Pringle, C. M. 1985. Effects of chironomid (Insecta: Diptera) tube-building activities on stream diatom communities. Journal of Phycology 21: 185-194.

Quataert, E., C. Storlazzi, A. van Rooijen, O. Cheriton, \& A. van Dongeren, 2015. The influence of coral reefs and climate change on wave-driven flooding of tropical coastlines. Geophysical Research Letters 42: 6407-6415. 
Reinhardt, L., D. Jerolmack, B. J. Cardinale, V. Vanacker, \& J. Wright, 2010. Dynamic interactions of life and its landscape: Feedbacks at the interface of geomorphology and ecology. Earth Surface Processes and Landforms 35: 78-101.

Resh, V. H., A. V Brown, A. P. Covich, M. E. Gurtz, H. W. Li, G. W. Minshall, S. R. Reice, A. L. Sheldon, J. B. Wallace, \& R. C. Wissmar, 1988. The role of disturbance in stream ecology. Journal of the North American Benthological Society 7: 433-455.

Rice, S., M. Johnson, \& I. Reid, 2012. Animals and the geomorphology of gravel-bed rivers In Church, M., P. Biron, \& A. Roy (eds), Gravel-bed Rivers: Processes, Tools, Environments. John Wiley and Sons, Chichester: 225-241.

Romero, G. Q., T. Gonçalves-Souza, C. Vieira, \& J. Koricheva, 2015. Ecosystem engineering effects on species diversity across ecosystems: A meta-analysis. Biological Reviews 90: 877-890.

Runde, J., \& R. Hellenthal, 2000. Effects of suspended particles on net-tending behaviors for Hydropsyche sparna (Trichoptera: Hydropsychidae) and related species. Annals of the Entomological Society of America 93: 678-683.

Sand-Jensen, K., 1998. Influence of submerged macrophytes on sediment composition and near-bed flow in lowland streams. Freshwater Biology 39: 663-679.

Song, J. X., X. H. Chen, \& C. Cheng, 2010. Observation of bioturbation and hyporheic flux in streambeds. Frontiers of Environmental Science \& Engineering in China 4: 340-348.

Statzner, B., M. F. Arens, J. Y. Champagne, R. Morel, \& E. Herouin, 1999. Silk-producing stream insects and gravel erosion: Significant biological effects on critical shear stress. Water Resources Research 35: $3495-3506$.

Tongway, D. J., J. A. Ludwig, \& W. G. Whitford, 1989. Mulga log mounds: Fertile patches in the semiarid woodlands of eastern Australia. Australian Journal of Ecology 14: 263-268.

Tumolo, B. B., L. K. Albertson, W. F. Cross, M. D. Daniels, \& L. S. Sklar, 2019. Occupied and abandoned structures from ecosystem engineering differentially facilitate stream community colonization. Ecosphere 10: e02734. 
Valett, H. M., \& J. A. Stanford, 1987. Food quality and hydropsychid caddisfly density in a lake outlet stream in Glacier National Park, Montana, USA. Canadian Journal of Fisheries and Aquatic Sciences 44: 77-82.

Vannote, R. L., G. W. Minshall, K. W. Cummins, J. R. Sedell, \& C. E. Cushing, 1980. River continuum concept. Canadian Journal of Fisheries and Aquatic Sciences 37: 130-137.

Walker, T. R., \& J. Grant, 2009. Quantifying erosion rates and stability of bottom sediments at mussel aquaculture sites in Prince Edward Island, Canada. Journal of Marine Systems 75: 46-55.

Wallace, J. B., \& J. R. Webster, 1996. The role of macroinvertebrates in stream ecosystem function. Annual Review of Entomology 41: 115-139.

Webert, K. C., C. M. Herren, Á. Einarsson, M. Bartrons, U. Hauptfleisch, \& A. R. Ives, 2017. Midgestabilized sediment drives the composition of benthic cladoceran communities in Lake Mývatn, Iceland.

Ecosphere 8: e01659.

Wiggins, G. B., 1977. Larvae of the North American Caddisfly Genera. Toronto University Press.

Wiggins, G. B., 2007. Caddisflies: Architechts under water. American Entomologist 53: 78-85. Wilcock, P. R., 1996. Estimating local bed shear stress from velocity observations. Water Resources Research 32: 3361-3366.

Wilson, K. A., J. J. Magnuson, D. M. Lodge, A. M. Hill, T. K. Kratz, W. L. Perry, \& T. V Willis, 2004. A long-term rusty crayfish (Orconectes rusticus) invasion: dispersal patterns and community change in a north temperate lake. Canadian Journal of Fisheries and Aquatic Sciences 61: 2255-2266.

Wright, J., \& C. G. Jones, 2006. The concept of organisms as ecosystem engineers ten years on: Progress, limitations, and challenges. BioScience 56: 203-209.

Zanetell, B., \& B. L. Peckarsky, 1996. Stoneflies as ecological engineers-hungry predators reduce fine sediments in stream beds. Freshwater Biology 36: 569-577.

Zuur, A. F., E. N. Ieno, N. Walker, A. A. Saveliev, \& G. M. Smith, 2009. Mixed effects models and extensions in ecology with R. Statistics. Springer New York, New York, NY. 


\section{Tables}

Table 1: Kenward-Roger analysis of variance (ANOVA) table with Kenward-Roger approximations for degrees of freedom testing for differences in velocity among locations around retreats across the eight sampling dates of the experiment (day). Significant values $(\mathbf{P}<\mathbf{0 . 0 5})$.

Velocity ( $\left.\mathrm{m} \mathrm{s}^{-1}\right)$

\begin{tabular}{lllll} 
Source of Variation & Num. df & Den. df & F & P \\
\hline Location & 2 & 384 & 484.21 & $\mathbf{0 . 0 0 1}$ \\
Day & 7 & 167 & 2.84 & $\mathbf{0 . 0 0 8}$ \\
Location x Day & 14 & 384 & 1.55 & 0.092
\end{tabular}

Table 2: Post-hoc tests of Kenward-Roger comparisons (see Table 1) between control, downstream, and upstream locations across the eight sampling dates of the experiment based on estimates of least squares means of Vx. Significant values $(\mathbf{P}<\mathbf{0 . 0 5})$.

Velocity (Vx)

\begin{tabular}{lllll}
\hline Contrast & LS means & df & t & P \\
\hline Control-Downstream & 0.19 & 384 & 28.66 & $\mathbf{0 . 0 0 1}$ \\
Control-Upstream & 0.04 & 385 & 3.88 & $\mathbf{0 . 0 0 1}$ \\
Downstream-Upstream & -0.16 & 385 & -24.86 & $\mathbf{0 . 0 0 1}$
\end{tabular}

Table 3: Kenward-Roger analysis of variance (ANOVA) table with Kenward-Roger approximations for degrees of freedom testing for differences in retreat height among persistence levels across the eight sampling dates of the experiment. Significant values $(\mathbf{P}<\mathbf{0 . 0 5})$.

Retreat Height

\begin{tabular}{lllll}
\hline Source of Variation & Num. df & Den.df & F & P \\
\hline Day & 7 & 165 & 9.08 & $\mathbf{0 . 0 0 1}$ \\
Persistence & 2 & 26 & 2.66 & 0.088 \\
Persistence x Day & 11 & 165 & 1.88 & $\mathbf{0 . 0 4 6}$
\end{tabular}




\section{Figures}

Fig. 1 Experimental design schematic showing (a) aerial view of an example of a holding flume that housed paired retreat and control rocks for the 61-day experiment, (b) the experimental working flume where the retreat or control rocks were carefully moved by hand into a working patch surrounded by similarly sized sediments, and (c,d) side view of the position of measurements in the experimental flume for either retreat or control rocks where velocity measurements were made along the smooth surface for controls and both up- and downstream of the caddisfly structure for retreats.
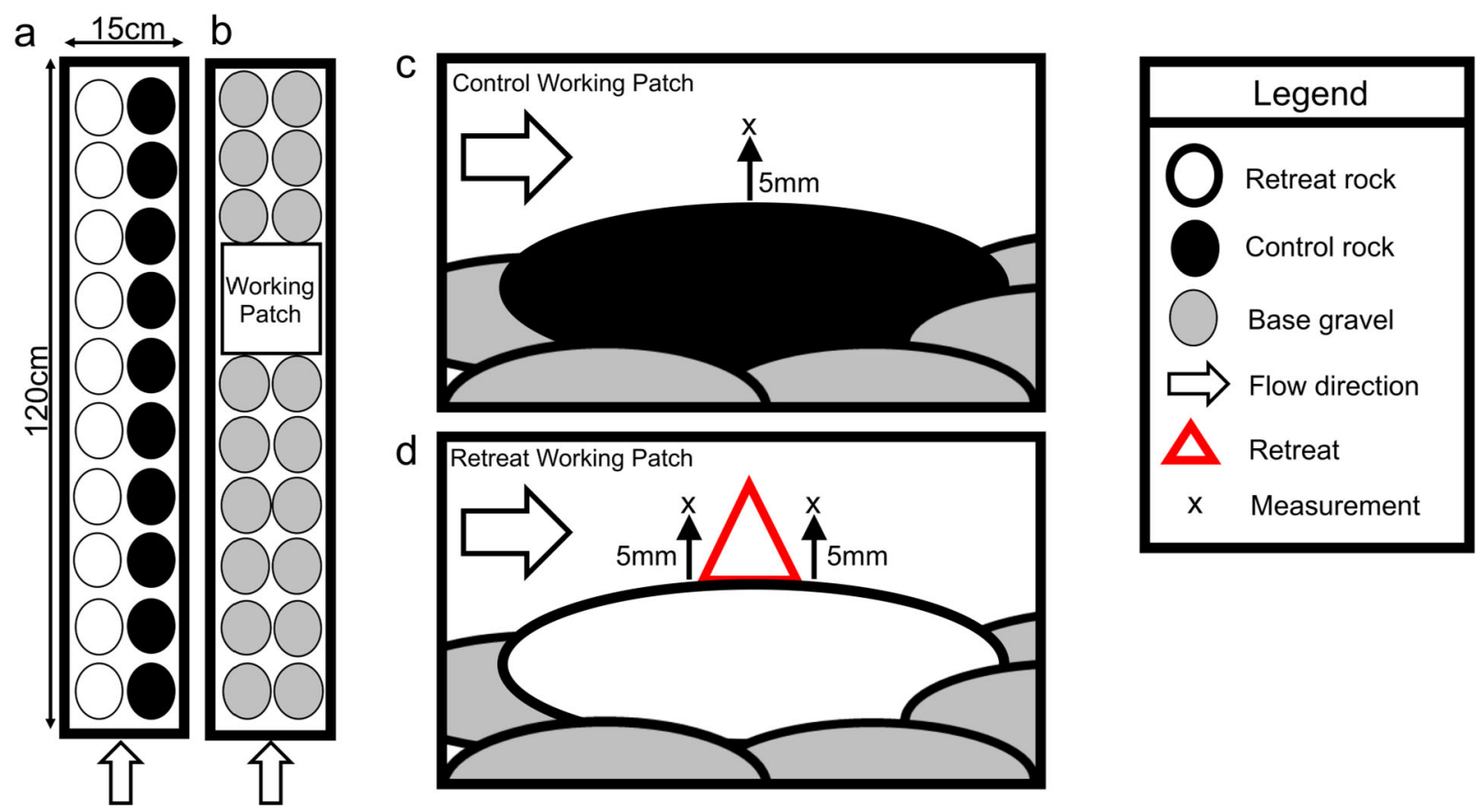
Fig. 2 Velocity $\left(\mathrm{m} \mathrm{s}^{-1}\right)$ measurements (mean $\pm \mathrm{SE}$ ) compared among control (solid black circle), upstream (open triangle), and downstream (open rectangle) sampling location treatments across the eight sampling dates of the experiment.

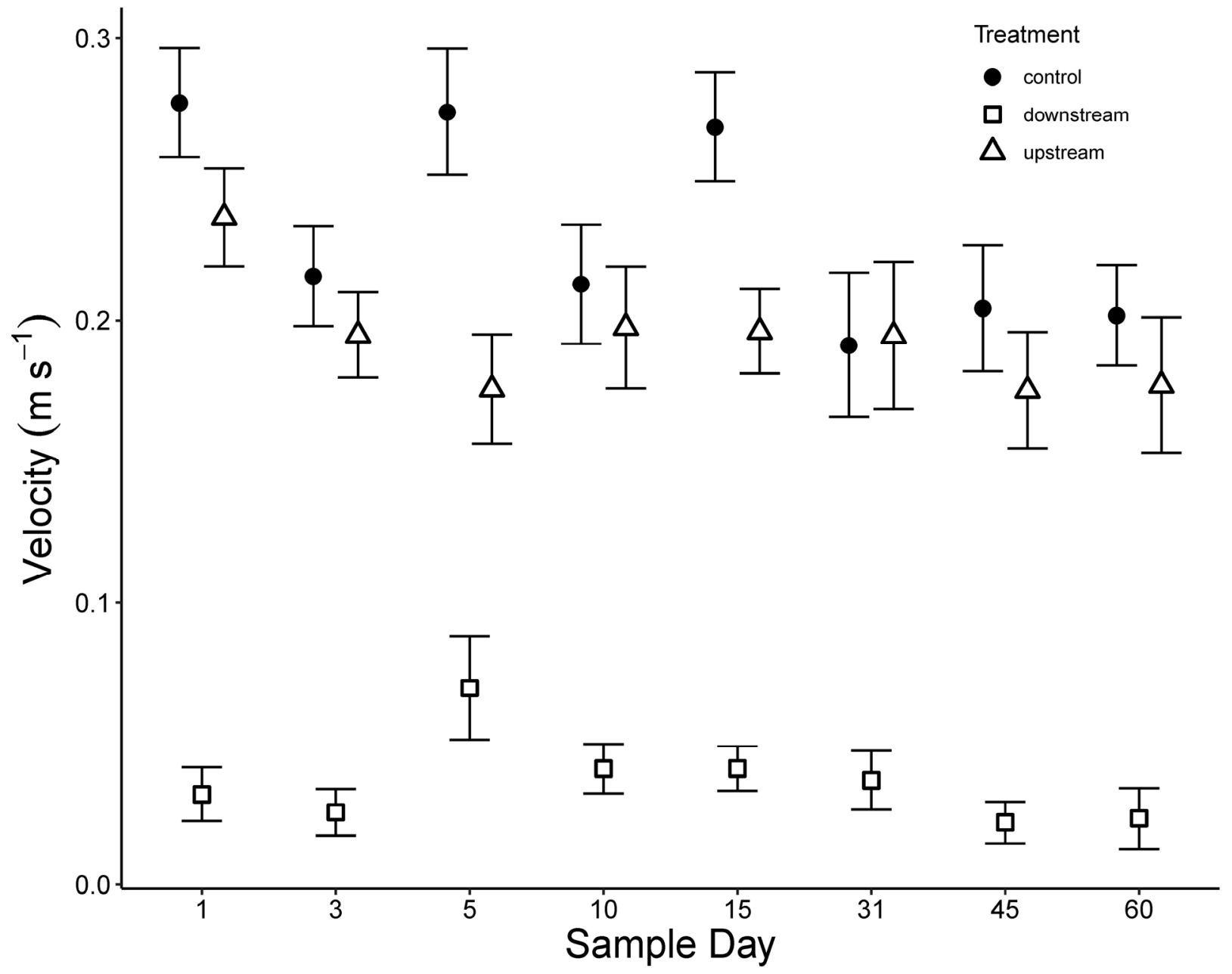


Fig. 3 Number of retreats that remained and held their structure over the duration of the experiment.

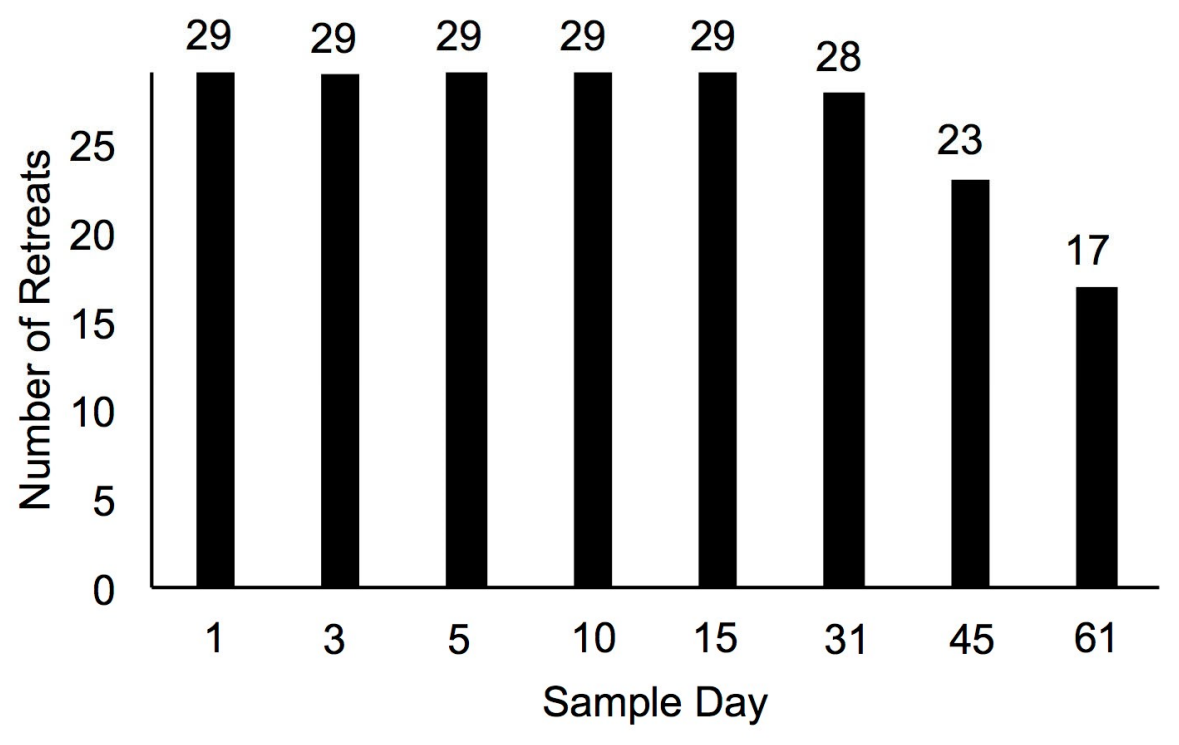

Fig. 4 Mean retreat height over the duration of the experiment categorized by retreat persistence level with lines of best fit. Persistence was categorized as retreats that lasted 31 (low, open black circle), 45 
(medium, closed grey circle), or 61 (high, closed black circle) days. Retreats that lasted longer (high persistence) were more likely to maintain their starting height over the duration of the experiment.

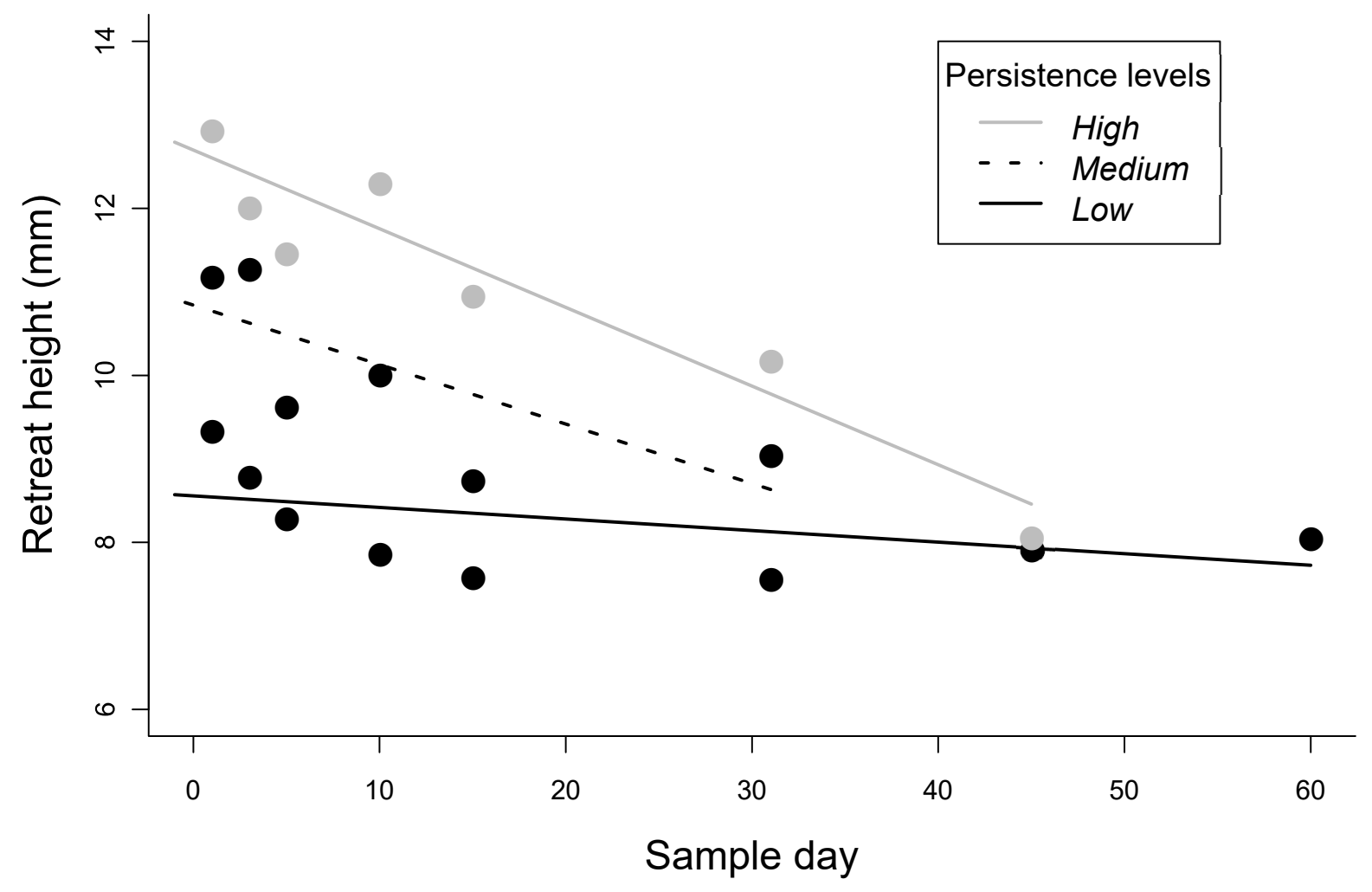

Supplemental Information

Retreat but no surrender: Net-spinning caddisfly (Hydropsychidae) silk has enduring effects on stream 
channel hydraulics

Zachary Maguire $^{1}$, Benjamin B. Tumolo ${ }^{1}$, and Lindsey K. Albertson ${ }^{1}$

Author affiliation: ${ }^{1}$ Department of Ecology, Montana State University, Bozeman, MT, 59717, USA

Corresponding author: Lindsey K. Albertson, PO Box 173460, Montana State University, Bozeman, MT, 59717, USA; Tel: (406) 994-3725; Email: lindsey.albertson@montana.edu 


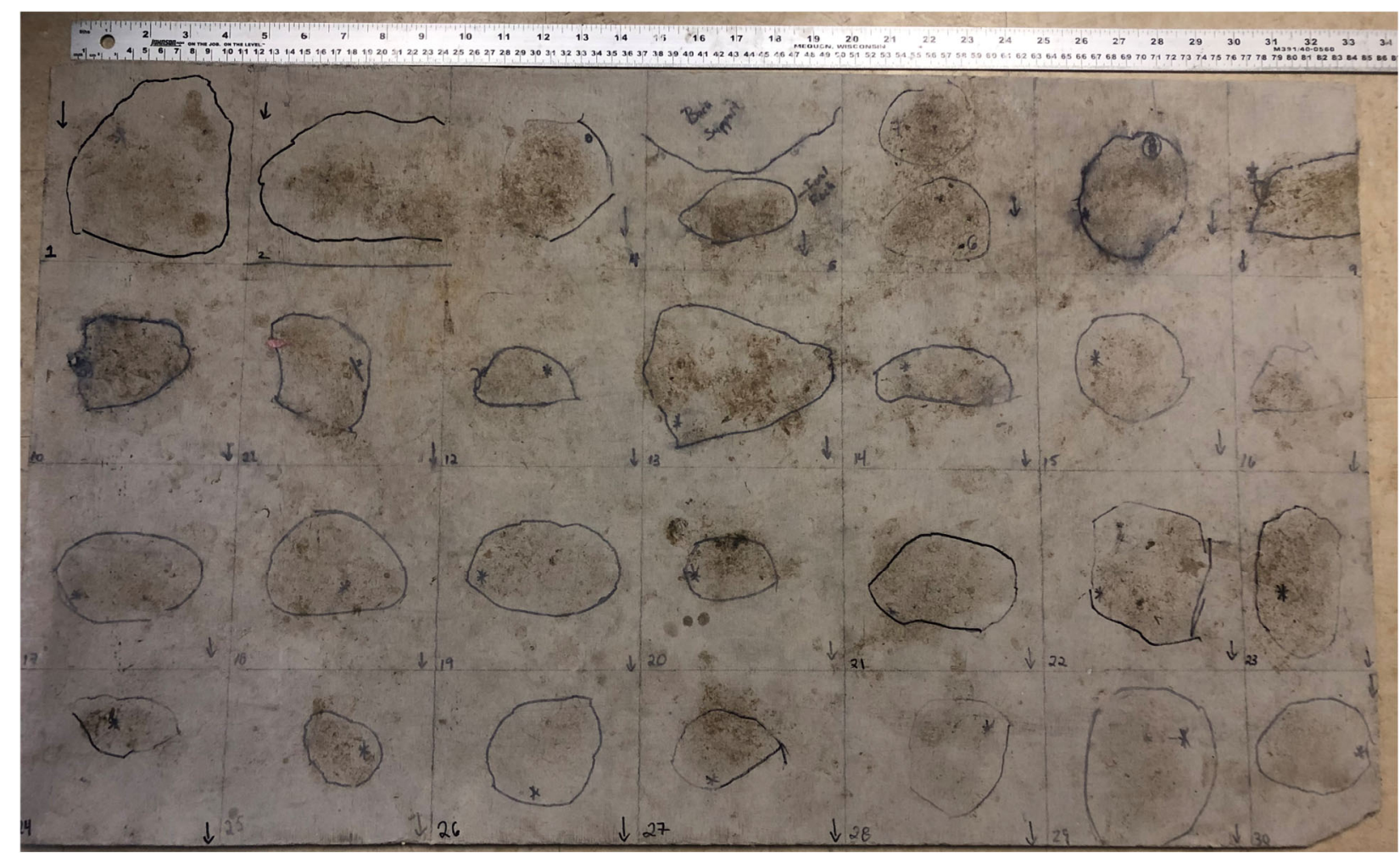

Fig. S1 Aerial view of landmarked stencil grid made to facilitate precise photographs of retreats for the retreat height analysis. Marker outlines delineate the rock border to ensure the exact same orientation and the asterisk within outline represents location of the retreat. The camera was placed at the same location on the lower edge of the stencil perpendicular to the retreat's location and a single photograph was taken prior to velocity measurements on each sampling day. 


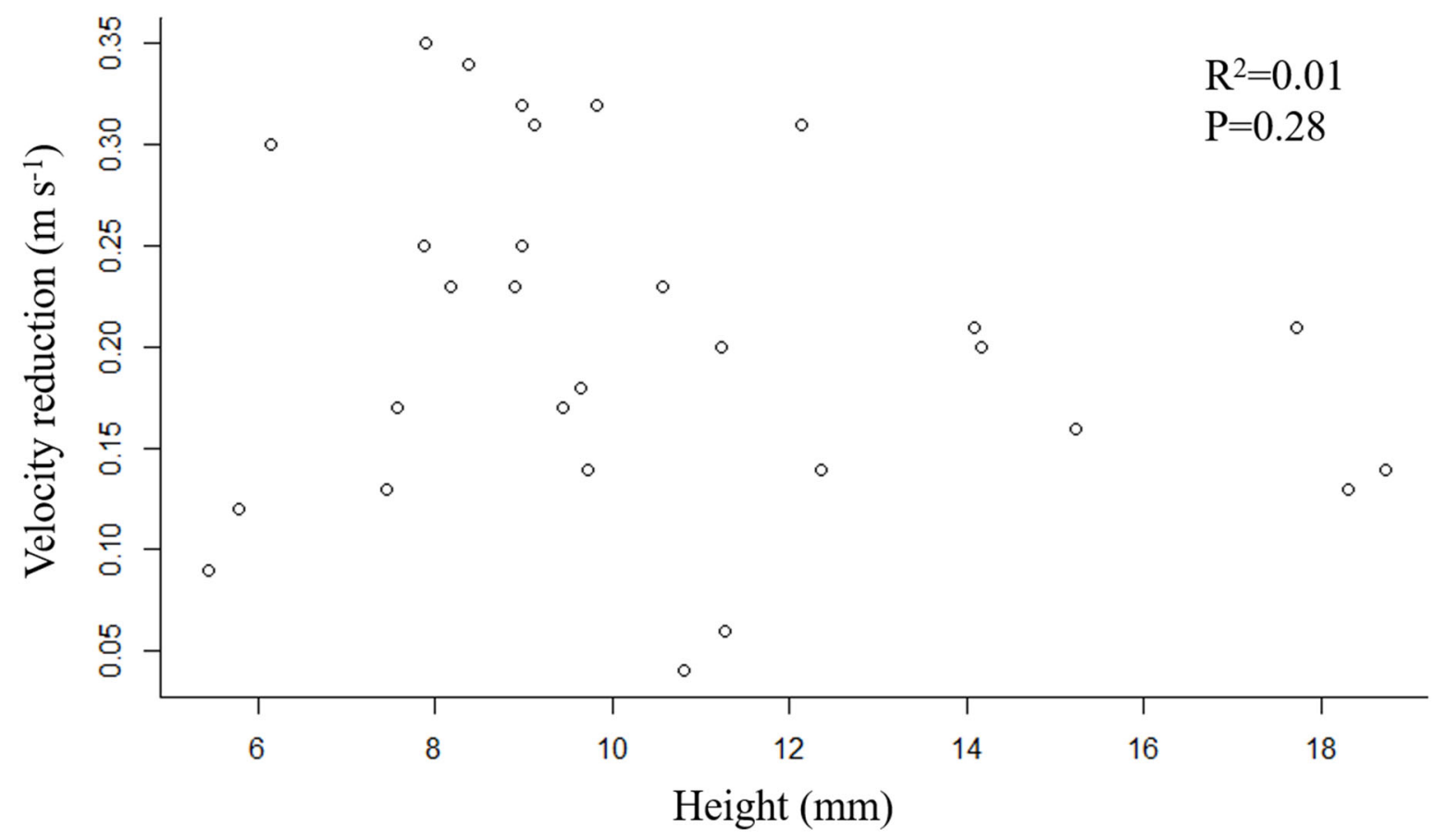

Fig. S2 Correlation of retreat height with water velocity reduction (calculated as upstream velocity minus downstream velocity; $\mathrm{m} \mathrm{s}^{-1}$ ) for day 1 of the experiment revealed no relationship between retreat size and a reduction in water velocity. Data are pooled across all experimental treatments $(\mathrm{N}=29)$. 


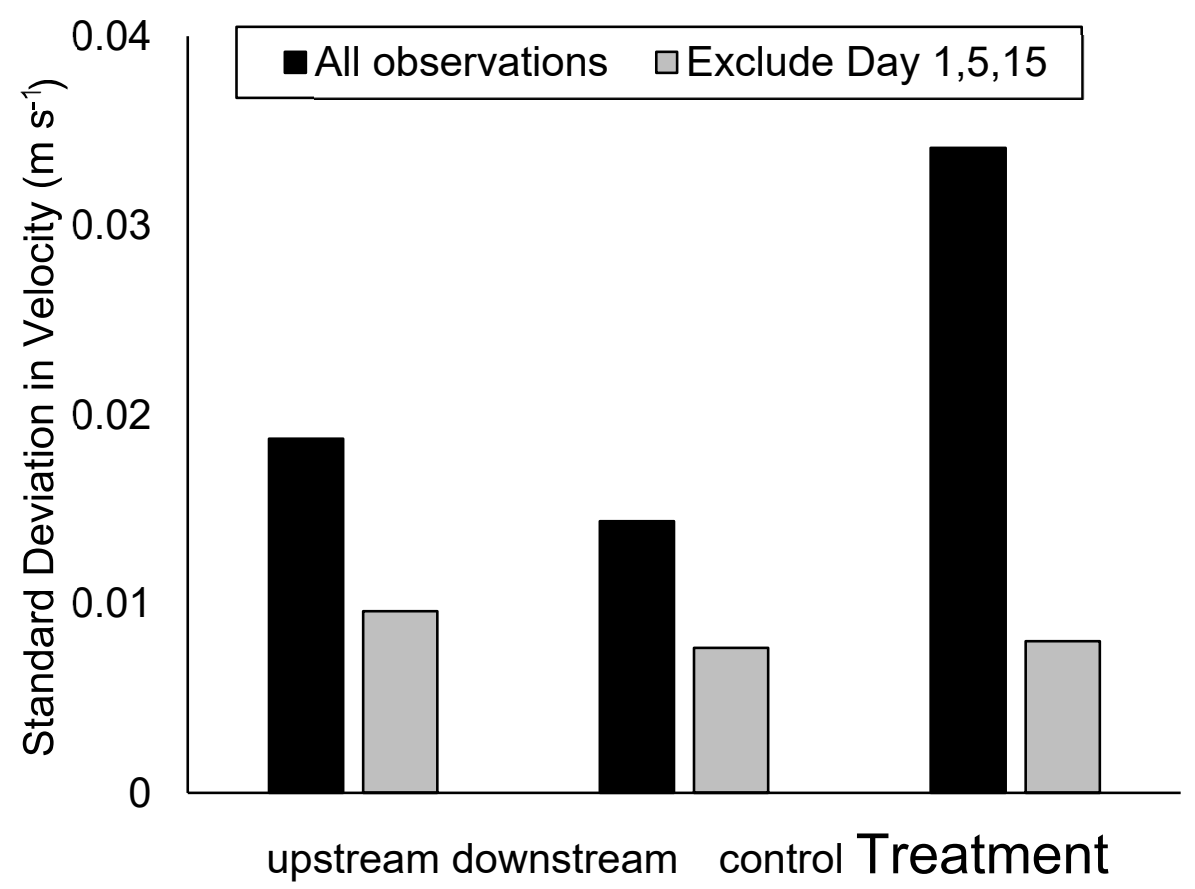

Fig. S3 Measured standard deviation of velocity (m s-1) among treatments across all of the sampling observations (Days 1, 3, 5, 10, 15, 30, 45, 60; black bars) and with the exclusion of days 1, 5, and 15, (gray bars). Measurements of velocity on days 1, 5,15 make a strong contribution to the observed interday variation among treatments, and variation was consistently lower for all treatments when Day 1 , 5 , and 15 were excluded. 